\title{
Polymorphisms in estrogen-metabolizing and estrogen receptor genes and the risk of developing breast cancer among a cohort of women with benign breast disease
}

\author{
Lisa Gallicchio*1,2, Sonja I Berndt ${ }^{1}$, Meghan A McSorley ${ }^{1}$, \\ Craig J Newschaffer ${ }^{1}$, Lucy W Thuita ${ }^{1}$, Pedram Argani ${ }^{3}$, Sandra C Hoffman ${ }^{1}$ \\ and Kathy J Helzlsouer ${ }^{1,2}$
}

\begin{abstract}
Address: ${ }^{1}$ Department of Epidemiology, Johns Hopkins Bloomberg School of Public Health, Baltimore, Maryland, USA, ${ }^{2}$ Prevention and Research Center, The Weinberg Center for Women's Health and Medicine, Mercy Medical Center, Baltimore, Maryland, USA and ${ }^{3}$ Department of Pathology, Johns Hopkins School of Medicine, Baltimore, Maryland, USA

Email: Lisa Gallicchio* - lgallic@mdmercy.com; Sonja I Berndt - sberndt@jhsph.edu;

Meghan A McSorley - mcsorley.meghan@medstudent.pitt.edu; Craig J Newschaffer - cnewscha@jhsph.edu; Lucy W Thuita - lthuita@jhsph.edu;

Pedram Argani - pargani1@jhmi.edu; Sandra C Hoffman - shoffman@jhsph.edu; Kathy J Helzlsouer - khelzlso@mdmercy.com

* Corresponding author
\end{abstract}

Published: 29 June 2006

BMC Cancer 2006, 6:173 doi:10.1186/147/-2407-6-173

This article is available from: http://www.biomedcentral.com//47/-2407/6/173

(c) 2006 Gallicchio et al; licensee BioMed Central Ltd.

This is an Open Access article distributed under the terms of the Creative Commons Attribution License (http://creativecommons.org/licenses/by/2.0), which permits unrestricted use, distribution, and reproduction in any medium, provided the original work is properly cited.
Received: 24 February 2006

Accepted: 29 June 2006

\begin{abstract}
Background: A cohort study was conducted to examine the role of genetic polymorphisms in three estrogen metabolizing enzymes (COMT, CYPIAI, CYPIBI) and the two estrogen receptors $(E S R I, E S R 2)$ in the progression of benign breast disease (BBD) to breast cancer.

Methods: Among participants in an ongoing cohort study, 1438 Caucasian women had a breast biopsy for BBD and were successfully genotyped for at least one of the polymorphisms examined in this study. Genotypes were determined using DNA extracted from blood specimens collected in 1989. Incident cases of breast cancer occurring subsequent to BBD diagnosis up to 2003 were identified through cancer registries.
\end{abstract}

Results: Among all participants, the ESR2 $* 5772 G$ allele was associated with a significant decrease in the risk of breast cancer among women with BBD (Odds Ratio (OR) 0.38; $95 \%$ Confidence Interval $(\mathrm{Cl}) 0.15,0.96)$. Compared to the reference wild-type genotypes, marginally significant associations with the development of breast cancer were observed between carriers of the variant ESRI - I04062T allele (OR 0.70, 95\% Cl 0.45, I.09), the variant ESR2 *38A allele (OR I.40; $95 \% \mathrm{CI}$ $0.88,2.25)$, and the variant CYPIBI 453Ser allele (OR I.48, 95\% CI 0.95, 2.32).

Conclusion: The results indicate that specific polymorphisms in the CYPIBI, ESRI, and ESR2 genes may play a role in progression of BBD to breast cancer among Caucasian women. Although additional studies are needed to confirm or refute our findings, these results suggest that genetic markers may aid in the identification of women who are at risk for progression of BBD to cancer. 


\section{Background}

Biopsy-proven benign breast disease (BBD) is a welldefined risk factor for developing invasive breast cancer $[1,2]$. However, little is known about which women with BBD progress to have a subsequent in situ or invasive cancer. A woman's level of endogenous estrogen may be important in the progression of BBD to invasive breast cancer. Abundant evidence suggests that estrogen is an important factor in the development of breast cancer among average-risk women. This evidence includes findings from recent prospective studies that showed significantly increased levels of serum estrogen in women who developed breast cancer compared to women who did not develop breast cancer [3-7]. In addition, numerous studies have reported that risk factors associated with prolonged estrogen exposure, such as early age at menarche, nulliparity, and older age at first birth, increase a woman's risk of developing breast cancer (reviewed by Mitrunen and Hirvonen [8]).

Because of the importance of estrogen in the development of breast cancer among average-risk women, it is plausible that polymorphisms in estrogen metabolizing genes may be associated with the risk of developing breast cancer among women with BBD. Estrogens undergo oxidative metabolism by several cytochrome P450 (CYPs) enzymes [9]; the major metabolic pathways are 2-hydroxylation, which is primarily catalyzed by CYP1A1, and 4-hydroxylation, which is dominated by CYP1B1 [10]. The hydroxylated estrogens are then either converted to semiquinones or quinones, which can produce DNA adducts and lead to oxidative damage to lipids and DNA, or inactivated by catechol O-methyltransferase (COMT) [10-13]. Within the genes encoding for CYP1A1, CYP1B1, and COMT, a number of polymorphisms have been identified, some which have been shown in laboratory studies to be functional (8). The associations of some of these polymorphisms with the risk of developing breast cancer among average risk women have been studied, and most of the findings have been inconsistent (reviewed in Mitrunen and Hirvonen [8]). No study has examined the associations of polymorphisms in CYP1A1, CYP1B1, and COMT with breast cancer risk among women with BBD.

While the estrogen metabolizing enzymes may influence the levels of circulating endogenous estrogens and, therefore, contribute to breast cancer risk, the estrogen receptors determine, in part, the action of estrogens on the mammary gland. Estrogen acts on target tissues by binding to the estrogen receptors, which exist in two forms, ER$\alpha$ or ESR1 and ER- $\beta$ or ESR2 [14,15]. Like the estrogen metabolizing enzymes, a number of polymorphisms in both ER genes have been identified [16], and it has been hypothesized that these polymorphisms may increase or decrease a woman's breast cancer risk depending on the functional consequence of the polymorphism. Several studies have investigated the associations between polymorphisms in the ESR1 and ESR2 genes and the risk of breast cancer among average-risk women and have reported mixed results [16-29]. To our knowledge, however, no study has examined the associations of polymorphisms in ESR1 and ESR2 with breast cancer risk among women with BBD.

The aim of the present study was to analyze the associations between genetic polymorphisms in three estrogen metabolizing enzymes (COMT, CYP1A1, CYP1B1) and the two estrogen receptors (ESR1, ESR2) and the risk of developing breast cancer among women with BBD. To address this aim, data from a cohort of women with BBD from Washington County, Maryland enrolled in the CLUE-II study were analyzed.

\section{Methods \\ CLUE II cohort}

In 1989, a campaign named CLUE II ("Campaign against Cancer and Heart Disease") was conducted in Washington County, Maryland to establish a cohort with associated blood samples [30]. At baseline, participants signed a consent form, completed a brief medical and exposure history and a food frequency questionnaire, and donated a blood sample. The blood sample was collected in heparinzed tubes and centrifuged to obtain separation of the buffy coat which was then aliquotted and stored at $-70^{\circ} \mathrm{C}$. DNA was subsequently extracted from the buffy coat using standard phenol extraction [31].

A total of 25,081 persons $(10,456$ men and 14,625 women), about 30 percent of the Washington County residents, participated in the study. In addition to the information collected from this cohort at baseline in 1989, follow-up data were obtained from questionnaires administered in 1996 and approximately every 2 years thereafter. The Institutional Review Board at the Johns Hopkins Bloomberg School of Public Health approved this study.

\section{BBD cohort}

The BBD cohort is a sub-set of CLUE II. Details of the selection of CLUE II participants included in the BBD cohort are described elsewhere [32]. Briefly, women who responded on the 1996 CLUE II follow-up questionnaire that they had undergone a "breast biopsy or lumpectomy" were considered for inclusion into the $\mathrm{BBD}$ cohort. Women were included in the BBD cohort if either they were found to have BBD on their first located pathology report or a pathology report was not found but a breast biopsy was reported prior to or in the absence of a subsequent breast cancer diagnosis. Women who were diagnosed with breast cancer at their first biopsy, as reported 
by the participant or as determined using the pathology report search, were excluded from this analysis. In total, of the 1683 women who reported that they had a breast biopsy, 1467 women $(87.2 \%)$ met the criteria above and were included in the BBD cohort. Among these 1467 women, pathology report data were collected for 362 $(24.7 \%)$. Seventy percent of these pathology reports indicated a diagnosis of non-proliferative BBD, 26\% indicated a diagnosis of proliferative disease without atypia, and $4 \%$ reported a diagnosis of proliferative disease with atypia.

For this analysis, 17 of the 1467 women were excluded because DNA could not be obtained from their stored blood samples and polymorphisms could not be genotyped. Further, all non-Caucasians $(n=12)$ were excluded from the analysis because previous studies have shown that race is an important confounder or effect modifier in investigations of polymorphisms and disease. These exclusions accounted from less than $1 \%$ of the BBD cohort. After applying these exclusions, the final analytic cohort included 1438 Caucasian women who were successfully genotyped for at least one of the genetic polymorphisms investigated in this study.

\section{Outcome measurement}

Incident cases of in situ or invasive breast cancer (International Classification of Diseases, Ninth Revision, code $233,174)$ were identified through linkage of the cohort participants with the Washington County Cancer Registry and, since 1992, with the Maryland State Cancer Registry. The Washington County Cancer Registry identifies cancer cases from discharge records and pathology reports from Washington County Hospital, which is the only hospital in the county, and from death certificates. Since 1992, all hospitals cancer diagnostic laboratories, and radiation therapy centers in Maryland have been required to report incident cancer cases to the Maryland Cancer Registry, and currently, the Maryland Cancer Registry is certified as being more than $95 \%$ complete by the North American Association of Central Cancer Registries. While it is possible that cases of in situ or invasive breast cancer may have been missed due to migration out of the state after 1996, all women in the BBD cohort had at least 7 years of follow-up data (1989 to 1996). Further, approximately $80 \%$ of the BBD cohort responded to the 2000 follow-up questionnaire, indicating that the vast majority of the cohort remained under active surveillance in 2000.

Active case surveillance for the BBD cohort ended on April 28,2003 . In total, among all of the women included in the BBD cohort, 15 incident cases of in situ and 76 cases of invasive breast cancer were identified after the diagnosis of BBD.

\section{Genotyping}

Single nucleotide polymorphisms (SNPs) analyzed in the present study were selected as part of a larger study investigating the broad impact of genetic variation in candidate genes and their interactions with environmental exposures on cancer incidence and survival. For the larger study, polymorphisms that were suggested to alter function, encoded for a nonsynonymous amino acid change, or were located within the $5^{\prime}$ or $3^{\prime}$ untranslated region (UTR) of the gene and thus could potentially alter mRNA stability were chosen. Descriptions and dbSNP identifiers of the polymorphisms selected are shown on Table 1 . Genotyping of the chosen SNPs in COMT, CYP1B1, CYP1A1, ESR1 and ESR2 was conducted at Applied Biosystems (ABI) and Celera Laboratories. All polymorphisms were genotyped using TaqMan technology (ABI, Foster City, CA, USA). The genotyping success rates of the polymorphisms selected ranged from $91.8 \%$ to $97.6 \%$, with the exception of the CYP1B1 Arg48Gly polymorphism for which the genotyping success rate was $84.2 \%$.

Table I: Description of single nucleotide polymorphisms examined in the progression of BBD to breast cancer

\begin{tabular}{|c|c|c|c|}
\hline Gene & $\mathrm{dbSNP}$ rs \# & snp description & Amino Acid Substitution \\
\hline COMT & 4680 & $E \times 3-12 G>A$ & Vall58Met \\
\hline CYPIAI & 1048943 & $E x 7+|3| A>G$ & Ile462Val \\
\hline CYPIBI & 1800440 & $E \times 3+3 \mid 5 A>G$ & Asn453Ser \\
\hline CYPIBI & 10012 & $E \times 2+143 C>G$ & Arg48Gly \\
\hline CYPIBI & 1056836 & $E \times 3+25 \mid G>C$ & Val432Leu \\
\hline ESRI & 1801132 & Ex4- I22G >C & Pro325Pro \\
\hline ESRI & 2077647 & $\mathrm{ExI}+392 \mathrm{~T}>\mathrm{C}$ & SerlOSer \\
\hline ESRI & 746432 & $E x|-| 92 G>C$ & Ala87Ala \\
\hline ESRI & 2273206 & IVS6+52G>T & \\
\hline ESRI & 851982 & $-104062 C>T$ & \\
\hline ESRI & 2228480 & $E x 8+229 G>A$ & Thr594Thr \\
\hline ESR2 & 4986938 & 38 bp $3^{\prime}$ of STP C>T & \\
\hline ESR2 & 928554 & 5659 bp $3^{\prime}$ of STP G>A & \\
\hline ESR2 & none & 5696 bp 3' of STP A>G & \\
\hline ESR2 & 8018687 & 5772 bp $3^{\prime}$ of STP $A>G$ & \\
\hline
\end{tabular}


The 84.2\% genotyping success rate for CYP1B1 Arg48Gly polymorphism was due to a problem with the laboratory assay that was not resolved during the study period.

\section{Statistical analysis}

The outcome variable examined in these analyses was the development of in situ or invasive breast cancer. Unconditional logistic regression was used to estimate ageadjusted odds ratios (ORs) and 95\% confidence intervals (95\% CIs) for the associations between the polymorphisms the development of breast cancer. Because previous studies indicate that the associations between several of the analyzed polymorphisms and the development of cancer may differ according to body mass index, smoking status, and alcohol intake, we conducted exploratory analyses to examine the associations between all of the polymorphisms and the development of breast cancer among strata of these variables (BMI: $<25 \mathrm{~kg} / \mathrm{m}^{2}, \geq 25 \mathrm{~kg} / \mathrm{m}^{2}$; smoking status: ever, never; alcohol intake: current, no current use). Further, these analyses were conducted for all participants and for pre- and post-menopausal participants separately. Because the number of events among the pre-menopausal women was low $(\mathrm{n}=24)$ and ORs for some of the genotypes could not be calculated, only the analyses for all participants and the post-menopausal subgroup are reported. As an additional exploratory analysis, logic regression [33] was employed using the software package $\mathrm{R} 2.0 .1$ to examine whether any interactions between the genotypes existed.

To address the issue of multiple testing in this study, p-values for the associations between single nucleotide polymorphisms and breast cancer risk were adjusted for the false discovery rate using the method proposed by Benjamini and Hochberg [34] in the software package R 2.0.1.

Unless otherwise specified, analyses were performed using SAS Version 8.2 (Cary, NC). A p-value of less than 0.05 was considered to be statistically significant.

\section{Results}

Characteristics of the analytic cohort are reported in Table 2 . The mean age of the participants was 53.5 years (standard deviation 12.1), and the majority of the women had at least a high school degree (82.2\%). Approximately $88 \%$ of the women had been pregnant at least once in their lifetime, $16.2 \%$ were current smokers, and $28.8 \%$ were current drinkers. Among the 1438 women in this sample, 91 (6.3\%) developed invasive or in situ breast cancer after an initial breast biopsy for BBD.

All of the polymorphisms examined were in Hardy-Weinberg equilibrium among women not developing breast cancer, with the exception of the CYP1B1 Ile462Val polymorphism ( $p$-value $=0.02)$. Although statistically signifi- cant, the observed genotype counts for the CYP1B1 Ile462 Val polymorphism were similar to the expected genotype counts under Hardy-Weinberg equilibrium (observed/expected: AA-1233/1229.5; AG-80/86.9; GG5/1.5). All ESR2 polymorphisms were in strong linkage disequilibrium ( $\left.\mathrm{D}^{\prime}>90\right)$. Among the ESR1 polymorphisms, the Ser10Ser and Ala87Ala polymorphisms were strongly linked (D' > 90).

The associations between polymorphisms in the estrogen metabolizing enzymes and the risk of developing invasive breast cancer among women with BBD are shown in Table 3. Among all participants and post-menopausal participants only, carriers of at least one CYP1B1 453Ser allele had a borderline statistically significant increase in the risk of developing breast cancer compared to women carrying the referent Asn/Asn genotype (all participants: OR $1.48,95 \%$ CI $0.95,2.32$; post-menopausal participants: OR $1.61 ; 95 \%$ CI $0.94,2.74)$. The other polymorphisms in the estrogen metabolizing enzymes were not associated with breast cancer risk among women with BBD in this study. Results were not substantially altered by BMI, alcohol intake or smoking status (results not shown). No significant interactions between the genotypes were observed. To note, after adjustment for multiple testing, none of the associations between polymorphisms in the estrogen metabolizing enzymes and the risk of developing invasive breast cancer were statistically significant.

The associations between polymorphisms in ESR1 and ESR2 and the risk of developing invasive breast cancer among women with BBD are shown in Tables 4 and 5. A marginally significant decrease in the risk of developing breast cancer was observed among carriers of the ESR1 $104062 \mathrm{~T}$ allele compared to carriers of the referent genotype (all participants: OR 0.70, 95\% CI 0.45, 1.09). Among all participants, the ESR2 $* 5772 \mathrm{G}$ allele was associated with a statistically significant decrease in the risk of breast cancer among women with BBD (OR 0.38; 95\% CI $0.15,0.96$ ). A marginally significant increase in the risk of developing cancer was observed among women carrying at least one ESR2 *38A allele compared to the women homozygous for the GG genotype (all participants: OR $1.40 ; 95 \%$ CI $0.88,2.25)$. OR estimates of the ESR2 *5772G and the ESR2 *38A polymorphisms were attenuated after adjustment for the presence of the other polymorphism (ESR2 *5772G OR 0.42; 95\% CI 0.17, 1.05; ESR2 *38 OR 1.27; 95\% CI 0.78, 2.04). Other ESR1 and ESR2 polymorphisms examined were not associated with breast cancer risk among women with BBD. Results did not differ substantially by BMI, alcohol intake or smoking status (results not shown). No significant interactions between the ESR1 and ESR2 genotypes were observed. After adjustment for multiple testing, the associations 
Table 2: Characteristics of the study cohort $(n=1438)$

\begin{tabular}{|c|c|c|}
\hline Characteristic & $\mathrm{n}$ & $\%$ \\
\hline \multicolumn{3}{|l|}{ Race } \\
\hline Caucasian & 1438 & 100.0 \\
\hline \multicolumn{3}{|l|}{ Age, years ${ }^{\mathrm{a}}$} \\
\hline$<50$ & 533 & 37.1 \\
\hline 50 to 60 & 411 & 28.6 \\
\hline$>60$ & 494 & 34.3 \\
\hline Missing & 0 & 0.0 \\
\hline \multicolumn{3}{|l|}{ Education, years ${ }^{\mathrm{a}}$} \\
\hline less than a high school degree & 259 & 18.0 \\
\hline high school degree & 714 & 49.7 \\
\hline some college & 463 & 32.2 \\
\hline Missing & 2 & 0.1 \\
\hline \multicolumn{3}{|l|}{ Menopausal status ${ }^{\mathrm{a}}$} \\
\hline Pre-menopausal & 377 & 26.2 \\
\hline Peri-menopausal & 35 & 2.4 \\
\hline Post-menopausal & 995 & 69.2 \\
\hline Missing & 31 & 2.2 \\
\hline \multicolumn{3}{|l|}{ Family history of breast cancer ${ }^{a}$} \\
\hline No & 715 & 49.7 \\
\hline Yes & 275 & 19.1 \\
\hline Missing & 448 & 31.2 \\
\hline \multicolumn{3}{|l|}{ Ever been pregnant $(\%)^{\mathrm{b}}$} \\
\hline No & 176 & 12.2 \\
\hline Yes & 1255 & 87.3 \\
\hline Missing & 7 & 0.5 \\
\hline \multicolumn{3}{|l|}{ Age at first birth (years, \%)b } \\
\hline Nulliparous & 176 & 12.2 \\
\hline 20 & 347 & 24.1 \\
\hline 20 to 24 & 539 & 37.5 \\
\hline$\geq 25$ & 339 & 23.6 \\
\hline Missing & 37 & 2.6 \\
\hline \multicolumn{3}{|l|}{ Age at menarche (years, \%) } \\
\hline$<12$ & 268 & 18.6 \\
\hline 12 to 13 & 763 & 53.1 \\
\hline$>13$ & 386 & 26.8 \\
\hline Missing & 21 & 1.5 \\
\hline \multicolumn{3}{|l|}{ Height, inches ${ }^{a}$} \\
\hline$<62$ & $4 I I$ & 28.6 \\
\hline $62-64$ & 419 & 29.1 \\
\hline$>64$ & 608 & 42.3 \\
\hline Missing & 0 & 0.0 \\
\hline \multicolumn{3}{|l|}{ Weight, pounds ${ }^{\mathrm{a}}$} \\
\hline$<130$ & 354 & 24.6 \\
\hline $130-<145$ & 318 & 22.1 \\
\hline $145-<165$ & 377 & 26.2 \\
\hline$\geq 165$ & 387 & 26.9 \\
\hline Missing & 2 & 0.1 \\
\hline \multicolumn{3}{|l|}{ BMI, $\mathrm{kg} / \mathrm{m}^{2}$, a } \\
\hline$<24.9$ & 744 & 51.7 \\
\hline $25.0-29.9$ & 433 & 30.1 \\
\hline$\geq 30$ & 259 & 18.0 \\
\hline Missing & 2 & 0.1 \\
\hline \multicolumn{3}{|l|}{ Smoking status ${ }^{\mathrm{a}}$} \\
\hline Never & 839 & 58.3 \\
\hline Former & 366 & 25.5 \\
\hline Current & 232 & 16.1 \\
\hline Missing & 1 & 0.1 \\
\hline \multicolumn{3}{|l|}{ Current alcohol drinker ${ }^{\mathrm{a}}$} \\
\hline No & 814 & 56.6 \\
\hline
\end{tabular}


Table 2: Characteristics of the study cohort $(n=1438)$ (Continued)

\begin{tabular}{lll}
\hline Yes & 413 & 28.7 \\
Missing & 211 & 14.7 \\
\hline
\end{tabular}

a data from 1989 questionnaire

b data from 1996 questionnaire

between the ESR1 and ESR2 polymorphisms and breast cancer described above were not statistically significant.

\section{Discussion}

In this population-based cohort of women with BBD, there was evidence of an increased risk of breast cancer among women who carried the CYP1B1 453Ser allele compared to women who carried two copies of the CYP1B1 453Asn allele. None of the previously published studies on the CYP1B1 Asn453Ser polymorphism and breast cancer conducted among average-risk women reported an increase in risk of breast cancer associated with this polymorphism [35-38], including a recent metaanalysis that reported an OR of 0.91 (95\% CI 0.79, 1.04) associated with the heterozygous Asn/Ser genotype and an OR of 0.85 (95\% CI $0.54,1.34)$ associated with the homozygous Ser/Ser genotype [39]. However, functionality studies demonstrate that the CYP1B1 polymorphic variant is associated with both higher catalytic activity in converting estrogen to 4-hydroxy estrogens and greater levels of DNA damage [39-41]. This mechanism may be more relevant for progression among the subgroup of women with BBD who progress to breast cancer, thus it is reasonable to examine this association among women biopsy proven BBD.

A marginally significant positive association was observed for the ESR2 *38G>A. This finding is not consistent with results of published studies among either average-risk or high-risk women. Maguire et al [26] reported no increase in breast cancer risk associated with two copies of the variant ${ }^{*} 38 \mathrm{~A}$ allele among average-risk (OR $0.81 ; 95 \% \mathrm{CI}$ $0.50,1.31$ ) or high risk (OR 1.00; $95 \%$ CI $0.58,1.71$ ). In addition, Gold et al [16] observed that haplotypes containing the common ESR2 *38G allele were associated with an increased risk of breast cancer among Ashkenazi Jews. These differences in findings may be due to the different populations under study; Maguire et al [26] examined ESR2 polymorphisms among patients in Sweden and Gold et al (16) investigated ESR2 and breast cancer among the Ashkenazi Jews. Neither investigated the association of ESR2 polymorphisms among women diagnosed with BBD.

In addition, results from this study suggest that women with BBD who carry the ESR2 ${ }^{*} 5772 A>G$ polymorphism or the ESR1 - 104062C>T polymorphism are at decreased risk of developing breast cancer. To our knowledge, neither of these genotypes has been examined in women with BBD or among average risk women. The regions surrounding each polymorphism are well conserved with little recombination, therefore, it likely that, if the associations are real, the observed associations are due to linkage disequilibrium with another functional polymorphism in the region. No information on functionality is know for either ESR2 ${ }^{*} 5772 A>G$ or ESR1 $-104062 C>T$.

There was no evidence of an association between the other polymorphisms examined in this study, including those in COMT and CYP1A1, and breast cancer risk. Although no published study has investigated the COMT Val158Met and CYP1A1 Ile462Val polymorphisms in the progression of $\mathrm{BBD}$ to invasive breast cancer, previous studies of average-risk women have reported discrepant results regarding the association between the COMT Val158Met and the CYP1A1 Ile462Val polymorphisms and the risk of breast cancer $[8,42]$. Both polymorphisms have been observed to be functional; the COMT 158Met allele is associated with three- to four-fold decreased activity compared to the wildtype allele [43] and the CYP1A1 $462 \mathrm{Val}$ allele is consistent with higher enzyme activity [44]. Therefore, an association between these polymorphisms and breast cancer is biologically plausible and support the findings of studies that show an association between the polymorphisms and breast cancer risk. It may be, however, that both polymorphisms only modify the association between endogenous estrogens and the risk of breast cancer. Incorporating data on circulating estrogen concentrations may clarify the importance of carrying a specific genotype. Alternatively, it may also be that the effect of any single polymorphisms on the risk of breast cancer is small and that it is necessary to look at combinations of variants in the hormone metabolism pathway.

While this study provides novel information regarding the role of polymorphisms in estrogen metabolizing enzymes and the estrogen receptor genes in the progression of BBD to breast cancer, this study has several limitations inherent to its design. As reported in a previously published investigation on this cohort of women [32], pathology reports were not able to be obtained for all women who reported that they had undergone a surgical biopsy. This was due both to difficulties in obtaining permission for pathology review for some participants as well as to an inability to obtain records of biopsies done more than 15 to 20 years ago. Since concordance of finding a pathology report and report of biopsy among women granting permission for pathology review who reported that they had undergone 
Table 3: Associations between estrogen metabolizing polymorphisms and breast cancer risk in the BBD cohort

\begin{tabular}{|c|c|c|c|c|c|c|c|}
\hline & $\mathrm{dbSNP}$ rs\# & & & & & All Participants & Post- \\
\hline & & $\mathrm{n}$ & $\%$ & $\mathrm{n}$ & $\%$ & $\begin{array}{l}\text { Age- Adjusted } \\
\text { OR }(95 \% \mathrm{Cl})\end{array}$ & $\begin{array}{l}\text { Age- Adjusted } \\
\text { OR }(95 \% \mathrm{Cl})\end{array}$ \\
\hline $\begin{array}{l}\text { COMT } \\
\text { Vall } 58 \mathrm{Met}\end{array}$ & 4680 & & & & & & \\
\hline GG & & 16 & 17.6 & 272 & 20.2 & 1.00 & 1.00 \\
\hline GA & & $4 I$ & 45.1 & 608 & 45.1 & $1.15(0.63,2.08)$ & $0.89(0.45,1.77)$ \\
\hline AA & & 24 & 26.4 & 371 & 27.5 & $1.10(0.57,2.11)$ & $0.90(0.43,1.90)$ \\
\hline GA/AA & & 65 & 71.4 & 979 & 72.7 & $1.13(0.64,1.98)$ & $0.89(0.47,1.70)$ \\
\hline Missing & & 10 & 11.0 & 96 & 7.1 & & \\
\hline $\begin{array}{l}\text { CYPIAI } \\
\text { lle462Val }\end{array}$ & 1048943 & & & & & & \\
\hline AA & & 78 & 85.7 & 1233 & 91.5 & 1.00 & 1.00 \\
\hline AG & & 7 & 7.7 & 80 & 5.9 & $1.38(0.62,3.10)$ & $1.30(0.45,3.74)$ \\
\hline GG & & 1 & I.I & 5 & 0.4 & $\begin{array}{c}3.33(0.38 \\
28.99)\end{array}$ & $\begin{array}{c}8.33(0.74 \\
93.62)\end{array}$ \\
\hline p-for-trend & & & & & & 0.20 & 0.20 \\
\hline AG/GG & & 8 & 8.8 & 85 & 6.3 & $1.49(0.70,3.19)$ & $1.56(0.60,4.08)$ \\
\hline Missing & & 5 & 5.5 & 29 & 2.2 & & \\
\hline $\begin{array}{l}\text { CYPIBI } \\
\text { Asn453Ser }\end{array}$ & 1800440 & & & & & & \\
\hline AA & & 51 & 56.0 & 866 & 64.3 & 1.00 & 1.00 \\
\hline AG & & 31 & 34.1 & 358 & 26.6 & $\mathrm{I} .45(0.9 \mathrm{I}, 2.3 \mathrm{I})$ & I.5I $(0.87,2.65)$ \\
\hline GG & & 4 & 4.4 & 37 & 2.7 & $1.77(0.61,5.16)$ & $2.44(0.81,7.36)$ \\
\hline$p$-for-trend & & & & & & 0.08 & 0.05 \\
\hline AG/GG & & 35 & 38.5 & 395 & 29.3 & I.48 $(0.95,2.32)$ & $1.61(0.94,2.74)$ \\
\hline Missing & & 5 & 5.5 & 86 & 6.4 & & \\
\hline $\begin{array}{l}\text { CYPIBI } \\
\text { Arg48Gly }\end{array}$ & 10012 & & & & & & \\
\hline $\mathrm{CC}$ & & 39 & 42.9 & 600 & 44.5 & 1.00 & 1.00 \\
\hline CG & & 33 & 36.3 & 460 & 34.1 & $1.10(0.68,1.78)$ & $0.95(0.53,1.69)$ \\
\hline GG & & 3 & 3.3 & 76 & 5.6 & $0.60(0.18,2.00)$ & $0.25(0.03,1.88)$ \\
\hline CG/GG & & 36 & 39.6 & 536 & 39.8 & $1.02(0.65,1.64)$ & $0.84(0.48,1.50)$ \\
\hline Missing & & 16 & 17.6 & 211 & 15.7 & & \\
\hline $\begin{array}{l}\text { CYPIBI } \\
\text { Val432Leu }\end{array}$ & 1056836 & & & & & & \\
\hline $\mathrm{CC}$ & & 25 & 27.5 & 365 & 27.1 & 1.00 & 1.00 \\
\hline CG & & 39 & 42.9 & 653 & 48.5 & $0.88(0.53,1.48)$ & $1.04(0.56,1.98)$ \\
\hline GG & & 17 & 18.7 & 270 & 20.0 & $0.93(0.49,1.76)$ & $0.93(0.41,2.09)$ \\
\hline CG/GG & & 56 & 61.5 & 923 & 68.5 & $0.90(0.55,1.46)$ & $1.01(0.56,1.85)$ \\
\hline Missing & & 10 & 11.0 & 59 & 4.4 & & \\
\hline
\end{tabular}

a biopsy after 1980 was high (92.5\%), all women who reported a breast biopsy were included in the analyses. However, this may have led to the inclusion of a small number of women without BBD. Further, because data on the type of BBD were not collected for all participants, the analyses conducted in this study were not stratified by type of BBD, and, therefore, the ORs reported may underestimate (or overestimate) the true associations among women with certain types of BBD. 
Table 4: Associations between estrogen receptor-alpha (ESRI) polymorphisms and breast cancer risk in the BBD cohort

\begin{tabular}{|c|c|c|c|c|c|c|c|}
\hline & \multirow[t]{2}{*}{ dbSNP rs\# } & \multicolumn{2}{|c|}{$\begin{array}{l}\text { Cancer } \\
(\mathrm{n}=91)\end{array}$} & \multicolumn{2}{|c|}{$\begin{array}{l}\text { No Cancer } \\
(\mathrm{n}=1347)\end{array}$} & \multirow{2}{*}{$\begin{array}{l}\text { All Participants } \\
\text { Age- Adjusted } \\
\text { OR (95\% Cl) }\end{array}$} & \multirow{2}{*}{$\begin{array}{c}\text { Post- } \\
\text { menopausal } \\
\text { Only } \\
\text { Age-Adjusted } \\
\text { OR }(95 \% \mathrm{Cl})\end{array}$} \\
\hline & & $\mathrm{n}$ & $\%$ & $\mathrm{n}$ & $\%$ & & \\
\hline ESRI Pro325Pro & 1801132 & & & & & & \\
\hline $\mathrm{CC}$ & & 52 & 57.1 & 794 & 58.9 & 1.00 & 1.00 \\
\hline CG & & 31 & 34.1 & 440 & 32.7 & $1.07(0.67,1.69)$ & $1.06(0.6 \mathrm{I}, \mathrm{I} .87)$ \\
\hline GG & & 7 & 7.7 & 64 & 4.8 & $1.65(0.72,3.78)$ & $2.03(0.81,5.10)$ \\
\hline $\mathrm{CG} / \mathrm{GG}$ & & 38 & 41.8 & 504 & 37.4 & $1.14(0.74,1.76)$ & $1.19(0.70,2.01)$ \\
\hline Missing & & 1 & I.I & 49 & 3.6 & & \\
\hline ESRI SerlOSer & 2077647 & & & & & & \\
\hline TT & & 26 & 28.6 & 335 & 24.9 & 1.00 & 1.00 \\
\hline TC & & 36 & 39.6 & 642 & 47.7 & $0.71(0.42,1.20)$ & $0.90(0.46,1.77)$ \\
\hline $\mathrm{CC}$ & & 27 & 29.7 & 304 & 22.6 & $1.14(0.65,1.99)$ & $1.88(0.94,3.75)$ \\
\hline $\mathrm{TC} / \mathrm{CC}$ & & 63 & 69.2 & 946 & 68.8 & $0.85(0.53,1.37)$ & I.2I $(0.65,2.24)$ \\
\hline Missing & & 2 & 2.2 & 66 & 4.8 & & \\
\hline ESRI Ala87Ala & 746432 & & & & & & \\
\hline GG & & 67 & 73.6 & 1077 & 80.0 & 1.00 & 1.00 \\
\hline GC & & 15 & 16.5 & 181 & 13.4 & $1.32(0.74,2.36)$ & $1.24(0.61,2.51)$ \\
\hline $\mathrm{CC}$ & & I & I.I & 7 & 0.5 & $\begin{array}{c}2.30(0.28 \\
\quad 18.95)\end{array}$ & $\begin{array}{c}3.34(0.38 \\
29.18)\end{array}$ \\
\hline$p$-for-trend & & & & & & 0.3 & 0.3 \\
\hline $\mathrm{GC} / \mathrm{CC}$ & & 16 & 17.6 & 188 & 14.0 & $1.36(0.77,2.39)$ & I.3। $(0.66,2.60)$ \\
\hline Missing & & 8 & 8.8 & 82 & 6.1 & & \\
\hline ESRIIVS6+52 & 2273206 & & & & & & \\
\hline GG & & 69 & 75.8 & 1060 & 78.7 & 1.00 & 1.00 \\
\hline GT & & 13 & 14.3 & 229 & 17.0 & $0.86(0.48,1.59)$ & $0.71(0.33,1.53)$ \\
\hline TT & & 3 & 3.3 & 10 & 0.7 & $\begin{array}{c}4.79(1.29 \\
17.88)\end{array}$ & $\begin{array}{c}5.31(1.04 \\
27.28)\end{array}$ \\
\hline GT/TT & & 16 & 17.6 & 239 & 17.7 & $1.02(0.58,1.79)$ & $0.86(0.43,1.73)$ \\
\hline Missing & & 6 & 6.6 & 48 & 3.6 & & \\
\hline ESRI Thr594Thr & 2228480 & & & & & & \\
\hline$A A$ & & 2 & 2.2 & 41 & 3.0 & 1.00 & 1.00 \\
\hline AG & & 20 & 22.0 & 358 & 26.6 & $1.14(0.26,5.05)$ & $0.88(0.19,4.04)$ \\
\hline GG & & 58 & 63.7 & 841 & 62.4 & $1.42(0.34,6.01)$ & $0.86(0.20,3.77)$ \\
\hline AG/GG & & 78 & 85.7 & 1199 & 89.0 & $1.34(0.32,5.62)$ & $0.87(0.20,3.75)$ \\
\hline Missing & & 11 & 12.1 & 107 & 7.9 & & \\
\hline $\begin{array}{l}E S R I- \\
104062 C>T\end{array}$ & 851982 & & & & & & \\
\hline $\mathrm{CC}$ & & 38 & 41.8 & 470 & 34.9 & 1.00 & 1.00 \\
\hline $\mathrm{CT}$ & & 33 & 36.3 & 612 & 45.4 & $0.65(0.40,1.05)$ & $0.55(0.30,0.99)$ \\
\hline TT & & 14 & 15.4 & 190 & 14.1 & $0.88(0.47,1.67)$ & $0.89(0.43,1.85)$ \\
\hline $\mathrm{CT} / \mathrm{TT}$ & & 47 & 51.6 & 802 & 59.5 & $0.70(0.45,1.09)$ & $0.63(0.37,1.08)$ \\
\hline Missing & & 6 & 6.6 & 75 & 5.6 & & \\
\hline
\end{tabular}


Table 5: Associations between estrogen receptor-beta (ESR2) polymorphisms and breast cancer risk in the BBD cohort

\begin{tabular}{|c|c|c|c|c|c|c|c|}
\hline \multirow[b]{3}{*}{$\begin{array}{l}\text { ESR2 } 38 \text { bp 3' of } \\
\text { STP }\end{array}$} & \multirow[b]{2}{*}{$\mathrm{dbSNP}$ rs\# } & \multicolumn{2}{|c|}{$\begin{array}{l}\text { Cancer } \\
(n=91)\end{array}$} & \multicolumn{2}{|c|}{$\begin{array}{l}\text { No Cancer } \\
(\mathrm{n}=1347)\end{array}$} & \multirow{2}{*}{$\begin{array}{l}\text { All Participants } \\
\text { Age- Adjusted } \\
\text { OR }(95 \% \mathrm{Cl})\end{array}$} & \multirow{2}{*}{$\begin{array}{c}\text { Post- } \\
\text { menopausal } \\
\text { Only } \\
\text { Age-Adjusted } \\
\text { OR }(95 \% \mathrm{Cl})\end{array}$} \\
\hline & & $\mathrm{n}$ & $\%$ & $\mathrm{n}$ & $\%$ & & \\
\hline & 4986938 & & & & & & \\
\hline GG & & 26 & 28.6 & 470 & 34.9 & 1.00 & 1.00 \\
\hline GA & & 43 & 47.3 & 612 & 45.4 & $1.27(0.77,2.10)$ & $1.46(0.80,2.68)$ \\
\hline AA & & 19 & 20.9 & 190 & 14.1 & I.83 $(0.99,3.38)$ & I.7I $(0.78,3.76)$ \\
\hline p-for-trend & & & & & & 0.06 & 0.1 \\
\hline GA/AA & & 62 & 68.1 & 802 & 59.5 & $\mathrm{I} .40(0.88,2.25)$ & I.52 (0.85, 2.7I) \\
\hline Missing & & 3 & 3.3 & 75 & 5.6 & & \\
\hline $\begin{array}{l}\text { ESR2 } 5659 \mathrm{bp} 3^{\prime} \\
\text { of STP }\end{array}$ & 928554 & & & & & & \\
\hline GG & & 10 & 11.0 & 202 & 15.0 & 1.00 & 1.00 \\
\hline GA & & 44 & 48.4 & 632 & 46.9 & I.4I $(0.70,2.86)$ & $1.04(0.48,2.26)$ \\
\hline AA & & 28 & 30.8 & 419 & 31.1 & $1.38(0.66,2.89)$ & $0.88(0.38,2.05)$ \\
\hline GA/AA & & 72 & 79.1 & 1051 & 78.0 & $\mathrm{I} .40(0.7 \mathrm{I}, 2.76)$ & $0.98(0.47,2.06)$ \\
\hline Missing & & 9 & 9.9 & 94 & 7.0 & & \\
\hline $\begin{array}{l}\text { ESR2 } 5696 \text { bp 3' } \\
\text { of STP }\end{array}$ & none & & & & & & \\
\hline $\mathrm{AA}$ & & 75 & 82.4 & 1101 & 81.7 & 1.00 & 1.00 \\
\hline AG & & 12 & 13.2 & 180 & 13.4 & $0.96(0.5 \mathrm{I}, \mathrm{I} .8 \mathrm{I})$ & $0.74(0.33,1.67)$ \\
\hline GG & & 1 & 1.1 & 4 & 0.3 & $\begin{array}{c}3.68(0.41 \\
33.37)\end{array}$ & -- \\
\hline AG/GG & & 13 & 14.3 & 184 & 13.7 & $1.02(0.56,1.88)$ & $0.73(0.33,1.64)$ \\
\hline Missing & & 3 & 3.3 & 62 & 4.6 & & \\
\hline $\begin{array}{l}\text { ESR2 } 5772 \text { bp 3' } \\
\text { of STP }\end{array}$ & 8018687 & & & & & & \\
\hline AA & & 86 & 94.5 & 1133 & 84.1 & 1.00 & 1.00 \\
\hline AG & & 5 & 5.5 & 169 & 12.5 & $0.39(0.16,0.99)$ & $0.62(0.24,1.59)$ \\
\hline GG & & 0 & 0.0 & 5 & 0.4 & -- & -- \\
\hline AG/GG & & 5 & 5.5 & 174 & 12.9 & $0.38(0.15,0.96)$ & $0.61(0.24,1.55)$ \\
\hline Missing & & 0 & 0.0 & 40 & 3.0 & & \\
\hline
\end{tabular}

In addition, though the base cohort is relatively large, the number of cases of breast cancer occurring limited the power of the study to make firm conclusions about the relationships between polymorphisms in COMT, CYP1B1, CYP1A1, ESR1 and ESR2 and the risk of breast cancer in Caucasian women with BBD. We had limited power to detect small associations and, therefore, were also limited in our ability to correct for multiple testing. As stated in the results section, the associations between the polymorphisms and the risk of developing breast cancer were not statistically significant after correction for multiple testing and this may have been due, in part, to the small sample size. However, while we may be able to rule out large changes in risk of clinical and public health consequence associated with certain genotypes, we still observed, with the small number of events, statistically significant changes in the risk of breast cancer in this cohort. Taken together with functional considerations of these polymorphisms, it is important to follow-up on these observations to determine if we can better understand and perhaps intervene for those women with BBD who are most at risk to progress to cancer.

\section{Conclusion}

The findings of this study indicate that specific polymorphisms in the CYP1B1, ESR1, and ESR2 genes may play a role in progression of BBD to breast cancer among Caucasian women. Although additional studies are needed to 
confirm or refute our findings, these results suggest that genetic markers may aid in the identification of women who are at risk for progression of BBD to cancer.

\section{Abbreviations \\ BBD Benign breast disease}

COMT Catechol O-methyltransferase

CYPs Cytochrome P450 enzymes

ESR1 Estrogen receptor-alpha

ESR2 Estrogen receptor-beta

SNP Single nucleotide polymorphism

\section{Competing interests}

The author(s) declare that they have no competing interests.

\section{Authors' contributions}

LG contributed to the statistical analysis, interpretation of the data, and the writing of the manuscript. SIB provided expertise on the more advanced analyses of the genetic data and contributed to the interpretation of the data. MAM, LWT, and SAH contributed to the data collection and statistical analysis. PA conducted reviews of the pathology report data and pathology specimens. CJN and KJN contributed to the conception and design of the study and the interpretation of the data.

\section{Acknowledgements}

This research was supported by a National Cancer Institute SPORE grant CA8843 and a National Institute on Aging grant AG 18033 from the National Institutes of Health. The funding agencies had no role in the study design, collection, analysis and interpretation of the data, or in the writing of the manuscript. Dr. Gallicchio is supported by an Institutional National Research Service Award from the National Cancer Institute (T32 CA093 14). The authors thank Dr. Ingo Ruzcinski for providing his biostatistics expertise in this analysis. The authors thank Judy Bolton-Hoffman and Alyce Burke at the Comstock Center for Public Health Research and Prevention for their help in carrying out this study.

\section{References}

I. Wang J, Costantino JP, Tan-Chiu E, Wickerham DL, Paik S, Wolmark $\mathrm{N}$ : Lower-category benign breast disease and the risk of invasive breast cancer. J Natl Cancer Inst 2004, 96:616-620.

2. Hartman LC, Sellers TA, Frost MH, Lingle WL, Denghim AC, Ghosh K, Vierkant RA, Maloney SD, Pankratz VS, Hillman DW, Suman VJ, Johnson J, Blake C, Tlsty T, Vachon CM, Melton LJ, Visscher DW: Benign breast disease and the risk of breast cancer. $N$ Englj Med 2005, 353:229-237.

3. Missmer SA, Eliassen AH, Barbieri RL, Hankinson SE: Endogenous estrogen, androgen, and progesterone concentrations and breast cancer risk among postmenopausal women. J Natl Cancer Inst 2004, 96: 1856-1865.

4. Dorgan JF, Longcope C, Stephenson HEJ, Falk RT, Miller R, Franz C, Kahle L, Campbell WS, Tangrea JA, Schatzkin A: Serum sex hormone levels are related to breast cancer risk in postmenopausal women. Environ Health Perspect 1997, 105 Suppl 3:583-585.
5. Key T): Serum oestradiol and breast cancer risk. Endocr Relat Cancer 1999, 6: 175-180.

6. Key T, Appleby P, Barnes I, Reeves G: Endogenous sex hormones and breast cancer in postmenopausal women: reanalysis of nine prospective studies. J Natl Cancer Inst 2002, 94:606-6I6.

7. Kabuto M, Akiba S, Stevens RG, Neriishi K, Land CE: A prospective study of estradiol and breast cancer in Japanese women. Cancer Epidemiol Biomarkers Prev 2000, 9:575-579.

8. Mitrunen K, Hirvonen A: Molecular epidemiology of sporadic breast cancer. The role of polymorphic genes involved in oestrogen biosynthesis and metabolism. Mutat Res 2003, 544:9-41.

9. Thompson PA, Ambrosone C: Molecular epidemiology of genetic polymorphisms in estrogen metabolizing enzymes in human breast cancer. J Natl Cancer Inst Monogr 2000, 27: I 25-I34.

10. Zhu BT, Conney AH: Functional role of estrogen metabolism in target cells: review and perspectives. Carcinogenesis 1998, 19:1-27.

II. Liehr JG: Is estradiol a genotoxic mutagenic carcinogen? Endocr Rev 2000, $21: 40-54$

12. International Agency for Research on Cancer: Overall Evaluations of Carcinogenicity: An Updating of IARC Monographs. 1987, volumes I-42 (suppl. 6):

13. Yager JD: Endogenous estrogens as carcinogens through metabolic activation. J Natl Cancer Inst Monogr 2000:67-73.

14. Greene GL, Gilna P, Waterfield M, Baker A, Hort Y, Shine J: Sequence and expression of human estrogen receptor complementary DNA. Science 1986, 231: | I50-I| 54.

15. Mosselman S, Polman J, Dijkema R: ER beta: identification and characterization of a novel human estrogen receptor. FEBS Lett 1996, 392:49-53.

16. Gold B, Kalush F, Bergeron J, Scott K, Mitra N, Wilson K, Ellis N, Huang $H$, Chen M, Lippert R, Halldorsson BV, Woodworth B, White T, Clark AG, Parl FF, Broder S, Dean M, Offit K: Estrogen receptor genotypes and haplotypes associated with breast cancer risk. Cancer Res 2004, 64:889|-8900.

17. Roodi N, Bailey LR, Kao WY, Verrier CS, Yee CJ, Dupont WD, Parl FF: Estrogen receptor gene analysis in estrogen receptorpositive and receptor-negative primary breast cancer. J Natl Cancer Inst 1995, 87:446-45I.

18. Andersen TI, Heimdal KR, Skrede M, Tveit K, Berg K, Borresen AL: Oestrogen receptor (ESR) polymorphisms and breast cancer susceptibility. Hum Genet 1994, 94:665-670.

19. Iwase H, Greenman JM, Barnes DM, Hodgson S, Bobrow L, Mathew CG: Sequence variants of the estrogen receptor (ER) gene found in breast cancer patients with ER negative and progesterone receptor positive tumors. Cancer Lett 1996, 108: 179-184.

20. Wang H, Strobel HW: Regulation of CYP3A9 gene expression by estrogen and catalytic studies using cytochrome P450 3A9 expressed in Escherichia coli. Arch Biochem Biophys 1997, 344:365-372.

21. Cai Q, Shu XO, Jin F, Dai Q, Wen W, Cheng JR, Gao YT, Zheng W: Genetic polymorphisms in the estrogen receptor alpha gene and risk of breast cancer: results from the Shanghai Breast Cancer Study. Cancer Epidemiol Biomarkers Prev 2003, I 2:853-859.

22. Cai Q, Gao YT, Wen W, Shu XO, Jin F, Smith JR, Zheng W: Association of breast cancer risk with a GT dinucleotide repeat polymorphism upstream of the estrogen receptor-alpha gene. Cancer Res 2003, 63:5727-5730.

23. Southey MC, Batten LE, McCredie MR, Giles GG, Dite G, Hopper JL, Venter DJ: Estrogen receptor polymorphism at codon 325 and risk of breast cancer in women before age forty. J Natl Cancer Inst 1998, 90:532-536.

24. Schubert EL, Lee MK, Newman B, King MC: Single nucleotide polymorphisms (SNPs) in the estrogen receptor gene and breast cancer susceptibility. J Steroid Biochem Mol Biol 1999, 7I:2I-27.

25. Kang HJ, Kim SW, Kim HJ, Ahn SJ, Bae JY, Park SK, Kang D, Hirvonen $A$, Choe KJ, Noh DY: Polymorphisms in the estrogen receptoralpha gene and breast cancer risk. Cancer Lett 2002, I 78: $175-180$.

26. Maguire P, Margolin S, Skoglund J, Sun XF, Gustafsson JA, BorresenDale AL, Lindblom A: Estrogen Receptor Beta (ESR2) Polymorphisms in Familial and Sporadic Breast Cancer. Breast Cancer Res Treat 2005, 94:I45-I52. 
27. Onland-Moret NC, van Gils CH, Roest M, Grobbee DE, Peeters PH: The estrogen receptor alpha gene and breast cancer risk (The Netherlands). Cancer Causes Control 2005, I 6: I I 95- I 202.

28. Modugno F, Zmuda JM, Potter D, Cai C, Ziv E, Cummings SR, Stone $\mathrm{KL}$, Morin PA, Greene D, Cauley JA: Association of estrogen receptor alpha polymorphisms with breast cancer risk in older Caucasian women. Int J Cancer 2005, I I 6:984-99I.

29. Zheng SL, Zheng W, Chang BL, Shu XO, Cai Q, Yu H, Dai Q, Xu J, Gao YT: Joint effect of estrogen receptor beta sequence variants and endogenous estrogen exposure on breast cancer risk in Chinese women. Cancer Res 2003, 63:7624-7629.

30. Helzlsouer KJ, Alberg AJ, Huang HY, Hoffman SC, Strickland PT, Brock JW, Burse WW, Needham LL, Bell DA, Lavinge JA, Yager JD, Comstock GW: Serum concentrations of organochlorine compounds and the subsequent development of breast cancer. Cancer Epidemiol Biomarkers Prev 1999, 8:525-532.

31. Platz EA, De Marzo AM, Erlinger TP, Rifai N, Visvanathan K, Hoffman SC, Helzlsouer KJ: No association between pre-diagnostic plasma C-reactive protein concentration and subsequent prostate cancer. Prostate 2004, 59:393-400.

32. Gallicchio L, McSorley MA, Newschaffer CJ, Thuita LW, Huang HY, Hoffman SC, Helzlsouer KJ: Nonsteroidal anti-inflammatory drugs, cyclooxygenase polymorphisms, and the risk of developing breast cancer among women with benign breast disease. Cancer 2005, I 06(7): | 443-52.

33. Ruczinski I, Kooperberg C, LeBlanc ML: Exploring interactions in high-dimensional genomic data: an overview of Logic Regression, with applications. Journal of Multivariate Analysis 2004, 90:178-195.

34. Benjamini $Y$, Hochberg $Y$ : Controlling the false discovery rate: $a$ practical and powerful approach to multiple testing. I $R$ Stat Soc B 1995, 57:289-300.

35. Rylander-Rudqvist T, Wedren S, Granath F, Humphreys K, Ahlberg S, Weiderpass E, Oscarson M, Ingelman-Sundberg M, Persson I: Cytochrome P450 IB I gene polymorphisms and postmenopausal breast cancer risk. Carcinogenesis 2003, 24:I533-I539.

36. Bailey LR, Roodi N, Verrier CS, Yee CJ, Dupont WD, Parl FF: Breast cancer and CYPIAI, GSTMI, and GSTTI polymorphisms: evidence of a lack of association in Caucasians and African Americans. Cancer Res 1998, 58:65-70.

37. De VI, Hankinson SE, Li L, Colditz GA, Hunter DJ: Association of CYPIB I polymorphisms and breast cancer risk. Cancer Epidemiol Biomarkers Prev 2002, I I :489-492.

38. Bailey LR, Roodi N, Dupont WD, Parl FF: Association of cytochrome P450 IBI (CYPIBI) polymorphism with steroid receptor status in breast cancer. Cancer Res 1998, 58:5038-504I.

39. Wen W, Cai Q, Shu XO, Cheng JR, Parl F, Pierce L, Gao YT, Zheng W: Cytochrome P450 IBI and catechol-O-methyltransferase genetic polymorphisms and breast cancer risk in Chinese women: results from the shanghai breast cancer study and a meta-analysis. Cancer Epidemiol Biomarkers Prev 2005, | 4:329-335.

40. Hanna IH, Dawling S, Roodi N, Guengerich FP, Parl FF: Cytochrome P450 IBI (CYPIBI) pharmacogenetics: association of polymorphisms with functional differences in estrogen hydroxylation activity. Cancer Res 2000, 60:3440-3444

41. Shimada T, Watanabe J, Kawajiri K, Sutter TR, Guengerich FP, Gillam EM, Inoue K: Catalytic properties of polymorphic human cytochrome P450 IB I variants. Carcinogenesis I999, 20:I607-I6I3.

42. Le ML, Donlon T, Kolonel LN, Henderson BE, Wilkens LR: Estrogen metabolism-related genes and breast cancer risk: the multiethnic cohort study. Cancer Epidemiol Biomarkers Prev 2005, | 4:1998-2003

43. Lachman HM, Papolos DF, Saito T, Yu YM, Szumlanski CL, Weinshilboum RM: Human catechol-O-methyltransferase pharmacogenetics: description of a functional polymorphism and its potential application to neuropsychiatric disorders. Pharmacogenetics 1996, 6:243-250.

44. Landi MT, Sinha R, Lang NP, Kadlubar FF: Human cytochrome P450 I A2 . In IARC Scientific Publications Lyon, IARC; I999: I73-I 95.

\section{Pre-publication history}

The pre-publication history for this paper can be accessed here: http://www.biomedcentral.com/1471-2407/6/173/pre pub
Publish with Biomed Central and every scientist can read your work free of charge

"BioMed Central will be the most significant development for disseminating the results of biomedical research in our lifetime. "

Sir Paul Nurse, Cancer Research UK

Your research papers will be:

- available free of charge to the entire biomedical community

- peer reviewed and published immediately upon acceptance

- cited in PubMed and archived on PubMed Central

- yours - you keep the copyright

Submit your manuscript here:

http://www.biomedcentral.com/info/publishing_adv.asp
BioMedcentral 